\title{
Substitution of soybean meal with detoxified Jatropha curcas kernel meal: Effects on performance, nutrient utilization, and meat edibility of growing pigs
}

\author{
Yang $\mathrm{Li}^{1, \mathrm{a}}$, Ling Chen ${ }^{1, \mathrm{a}}$, Yuhui Zhang ${ }^{2}$, Jianmei $\mathrm{Wu}^{3}$, Yan Lin ${ }^{1}$, Zhengfeng Fang ${ }^{1}$, Lianqiang Che', \\ Shengyu $\mathrm{Xu}^{1}$, and $\mathrm{De} \mathrm{Wu}^{1, *}$
}

* Corresponding Author: De Wu
Tel: +86-835-2885017, Fax: +86-835-2885056,
E-mail: wude@sicau.edu.cn

'Key Laboratory for Animal Disease-Resistance Nutrition of the Ministry of Agriculture, Animal Nutrition Institute, Chengdu 611130, China ${ }^{2}$ College of Life Science, Sichuan Agricultural University, Ya'an, Sichuan 625014, China

${ }^{3}$ College of Food Science, Sichuan Agricultural University, Ya'an, Sichuan Province 625014, China

a These authors contributed equally to the work and should be regarded as co-first authors.

ORCID

Yang Li

https://orcid.org/0000-0001-5286-3121

Ling Chen

https://orcid.org/0000-0001-6023-8799

DeWu

https://orcid.org/0000-0003-1873-9914

Submitted Jul 1, 2017; Revised Aug 20, 2017; Accepted Nov 1, 2017
Objective: The study was conducted to investigate the effects of replacing soybean meal (SBM) with different levels of detoxified Jatropha curcas kernel meal (DJM) in growing pig diets on growth performance, nutrients digestibility and meat edibility.

Methods: A total of 144 pigs with initial body weight of $20.47 \pm 1.44 \mathrm{~kg}$, were randomly allocated to 6 dietary treatments with 6 replications per treatment and 4 pigs per replication for a period of 79 days. Six diets (DJM0, DJM15, DJM30, DJM45, DJM60, and DJM75) were formulated using DJM to replace $0 \%, 15 \%, 30 \%, 45 \%, 60 \%$, and $75 \%$ of SBM. From d 37 to 42 , feces and urine were total collected from six barrows in each treatment. At day 79, thirty-six pigs were slaughtered for sampling. The feed intake and weight gain were recorded, while the intestinal morphology, digestive enzyme activities, nutrient digestibility and the content of residual phorbol esters in muscles were determined.

Results: The results showed that increasing the replacement of SBM with DJM decreased the parameters including body weight, average daily gain, average daily feed intake, gain-tofeed ratio, weight and villus heights of duodenum, villus height and villus height/crypt depth of jejunum, digestive enzymes (protease, amylase, lipase, and trypsin) activities, and nutrients digestibility (nitrogen deposition, digestibility of nitrogen, energy digestibility, and total nitrogen utilization) (linear, $\mathrm{p}<0.05$; quadratic, $\mathrm{p}<0.05$ ) and there was no significant difference among DJM0, DJM15, and DJM30 in all measured indices. The highest diarrhea morbidity was observed in DJM75 $(\mathrm{p}<0.05)$. Phorbol esters were not detected in pig muscle tissues. Conclusion: The DJM was a good protein source for pigs, and could be used to replace SBM up to $30 \%$ (diet phorbol esters concentration at $5.5 \mathrm{mg} / \mathrm{kg}$ ) in growing pig diets with no detrimental impacts on growth performance, nutrient utilization, and meat edibility.

Keywords: Detoxified Jatropha curcas Kernel Meal; Enzyme Activities; Intestinal Morphology; Nutrient Utilization; Pigs; Soybean Meal

\section{INTRODUCTION}

Soybean meal (SBM) is still the most important protein source in the pig industries. Recently, SBM production has been continuously reduced globally, however, the demand for SBM has been increased, thus resulting in an increasing difference between the demand and production. According to statistics of SBM used in China, 70\% of SBM was imported from abroad. The increasing shortage of domestic supply for SBM has led to a soaring price of SBM and consequently reduced the profitability in pig production. Besides, SBM competes with human food heavily. Therefore, it is required to look for alternative feed sources to replace SBM [1].

Jatropha curcus is a member of Euphoiaceae family and widely cultivated in many tropical and subtropical regions, such as China, Africa, India, and South East Asia, because of 
its high oil content [2]. Jatropha curcus kernel meal, containing $48 \%$ to $64 \%$ crude protein (CP) after oil extraction, is an excellent alternative protein [3]. However, Jatropha curcas seeds were found to be toxic to animals, such as mice [4], rats [5], chickens, [6] and carps [7].The toxicity was ascribed to the presence of toxins or anti-nutritional factors including trypsin inhibitor, lectin (curcin), saponin, phytate, and phorbol esters. Researchers found that the trypsin inhibitor activity and lectin content in Jatropha curcus kernel meal were higher than those in SBM, and the only difference between non-toxic and toxic varieties of Jatropha curcas was that the toxic varieties had phorbol esters [8]. After heat and chemical treatment, trypsin inhibitor activity and lectin could be removed but not phorbol esters (PEs) $[9,10]$. So the most important toxin in detoxified Jatropha curcas kernel meal (DJM) was phorbol esters which may affect the edibility. There was a previous report that the DJM could be used in common carp diet to replace partially SBM or fish meal [11]. Our previous study had shown that DJM is a good protein source for growing pigs, and can replace $30 \%$ of SBM in the diet [12]. This study was conducted to investigate the effects of DJM in growing pigs on growth performance, enzymes activities, nutrient utilization, and meat edibility, and find out the optimal level of DJM for replacement of SBM.

\section{MATERIALS AND METHODS}

\section{Animal care}

The present experiment was conducted between September and December 2012 at the Research Farm of Animal Nutrition Institute, Sichuan Agricultural University, Yaan, China. The experimental protocol used in the present study was approved by the Animal Care and Use Committee of Sichuan Agricultural University.

\section{Animals and treatments}

A total of 144 crossbred (Duroc $\times$ Landrace $\times$ Yorkshire) growing pigs $(22.47 \pm 1.44 \mathrm{~kg})$ were allotted to six treatments for a 79 -day study on the basis of weight, age and sex. The treatments were the diets which replaced $0 \%, 15 \%, 30 \%, 45 \%, 60 \%$, and $75 \%$ of SBM with DJM expressed as DJM0, DJM15, DJM30, DJM45, DJM60, and DJM75, respectively. There were four pigs per pen ( 2 females and 2 males) and 6 pens per treatment.

\section{Diets and management}

The DJM (Table 1) used in this study was obtained from China National Offshore Oil Corporation (CNOOC). The seeds were shelled by husking machine and crushed by rod-toothed crushers bought from Jiangsu Zhengchang Co. Ltd. (Liyang, Jiangsu, China) and pressed into cakes to remove most of the oil which would be reduced to between $14 \%$ and $18 \%$. The residual oil and toxins were extracted by solvent-extracted No.6 fuel
Table 1. Proximate composition, anti-nutrients content and amino acid profile in Jatropha curcas kernel meal (as fed basis)

\begin{tabular}{|c|c|}
\hline Items & Laboratory analysis \\
\hline \multicolumn{2}{|l|}{ Proximate composition (\%) } \\
\hline Dry matter & 90 \\
\hline Crude protein & 58 \\
\hline Crude fat & 1.4 \\
\hline Crude fiber & 3.6 \\
\hline Ash & 9.33 \\
\hline Gross energy $(\mathrm{kJ} / \mathrm{g})$ & 13.19 \\
\hline Calcium & 0.86 \\
\hline Total phosphorus & 0.27 \\
\hline Available phosphorus & 0.12 \\
\hline $\begin{array}{l}\text { Anti-nutrients trypsin inhibitor } \\
\quad \text { (mg trypsin inhibited per g sample) }\end{array}$ & ND \\
\hline Lectin (mg/mL) & ND \\
\hline Phorbol esters (mg/g) & 0.11 \\
\hline \multicolumn{2}{|l|}{ Essential amino acids (\%) } \\
\hline Lysine & 1.91 \\
\hline Leucine & 3.83 \\
\hline Iso leucine & 2.61 \\
\hline Methionine & 0.66 \\
\hline Phenylalanine & 2.09 \\
\hline Valine & 2.07 \\
\hline Threonine & 1.98 \\
\hline Tryptopan & 0.71 \\
\hline Arginine & 7.28 \\
\hline Histidine & 1.63 \\
\hline \multicolumn{2}{|l|}{ Non-essential amino acids (\%) } \\
\hline Alanine & 2.66 \\
\hline Cystine & 0.38 \\
\hline Glycine & 2.34 \\
\hline Glutamic acid & 8.05 \\
\hline Proline & 2.24 \\
\hline Serine & 2.44 \\
\hline Tyrosine & 1.97 \\
\hline Aspartic acid & 4.62 \\
\hline
\end{tabular}

ND, not detected.

oil, and then the cakes were detoxified by steam treatment (pre-treatment $80^{\circ} \mathrm{C}$ and $90^{\circ} \mathrm{C}$ until dried) and ethyl alcohol extraction $\left(55^{\circ} \mathrm{C}\right.$ for $\left.2 \mathrm{~h}\right)$ to remove more PEs. The DJM samples were analyzed for moisture, crude fat, $\mathrm{CP}$, crude fiber, ash, calcium, phosphorus [13], amino acid profile [14,15], phorbol esters, trypsin inhibitors activities, and lectin content. Diets were based on corn and SBM and offered to pigs according to a 2-phase feeding programs with live weight from 20 to 50 $\mathrm{kg}$ and from 50 to $80 \mathrm{~kg}$. Diets (Tables 2,3) for each phase were formulated to meet energy and nutrient requirements for growing-finishing pigs as recommended by NRC [16]. Diets were both iso-nitrogenous and iso-calorific for digestible energy among treatments.

Pigs were housed in a totally enclosed room with 36 pens $(2.0 \times 2.5 \mathrm{~m})$. The room was mechanically ventilated, and tem- 
peratures in the room for each phase were $22^{\circ} \mathrm{C}$ to $28^{\circ} \mathrm{C}$ and $15^{\circ} \mathrm{C}$ to $22^{\circ} \mathrm{C}$, respectively. Each pen was equipped with a nipple drinking fountain and a feeding hopper $(2.0 \times 0.3 \mathrm{~m})$. Water and diets were provided ad libitum throughout the experimental period. Pigs were fed 3 times a day at 08:00, 14:00 and 18:00 h. A sufficient amount of feed was placed in the hopper to ensure that feed was always available. Meanwhile, the hoppers were checked daily to ensure ad libitum access and minimize feed wastage. Daily feed intake per pen was recorded to calculate average daily feed intake (ADFI) and pigs were weighted individually at the end of experiment to calculate average daily gain (ADG). Afterwards, gain-to-feed ratio (G:F) was calculated from ADFI and ADG. Besides, clinical observations (diarrhea and death) of pigs were recorded daily beginning on the first day of the experiment. Feces were assessed visually using the fecal consistency score according to Marquardt et al. [17] with a score from 1 to $3(1=$ well formed, 2 = sloppy, and 3 = diarrhea). The pigs that had diarrhea were identified so that it would not be counted twice. Diarrhea morbidity was calculated as the number of pigs with diarrhea divided by the total number of pigs in the treatment, and mortality was expressed as the number of dead pigs divided by the total number of pigs in the treatment.

At d 29, six borrows per treatment close to the average weight in each group were chosen and moved into metabolism cages for a 14-d experiment, including $8 \mathrm{~d}$ for adaption to metabolism cages and $6 \mathrm{~d}$ for total collection of feces and urine. Each cage was also equipped with a nipple drinking fountain and a feeding hopper. Water and diets were also obtained $a d$ libitum and daily feed intake per pig was recorded. The diets were same with those in Table 2. Pigs were also fed 3 times a day at 08:00, 14:00, and 18:00 $\mathrm{h}$, and the environmental control was same as before. At $\mathrm{d} 43$, the barrows were moved to their former pens.

Table 2. Ingredients and chemical composition of the different diets to growing pigs for 20 to $50 \mathrm{~kg}$ (as fed basis)

\begin{tabular}{|c|c|c|c|c|c|c|}
\hline \multirow{2}{*}{ Item } & \multicolumn{6}{|c|}{ Dietary treatments ${ }^{1)}$} \\
\hline & DJM0 & DJM15 & DJM30 & DJM45 & DJM60 & DJM75 \\
\hline \multicolumn{7}{|l|}{ Ingredients (\%) } \\
\hline Corn & 70.63 & 71.57 & 72.49 & 73.43 & 74.38 & 75.33 \\
\hline Soybean meal| ${ }^{2)}$ & 21.95 & 18.48 & 15.04 & 11.57 & 8.10 & 4.63 \\
\hline Fish meal ${ }^{2)}$ & 2.11 & 2.11 & 2.11 & 2.11 & 2.11 & 2.11 \\
\hline Detoxified Jatropha curcas kernel meal ${ }^{2)}$ & 0.00 & 2.50 & 5.00 & 7.50 & 10.00 & 12.50 \\
\hline Soybean oil & 3.00 & 3.00 & 3.00 & 3.00 & 3.00 & 3.00 \\
\hline Limestone & 0.88 & 0.87 & 0.83 & 0.78 & 0.75 & 0.72 \\
\hline Monocalcium phosphate & 0.32 & 0.32 & 0.34 & 0.38 & 0.38 & 0.39 \\
\hline Choline & 0.10 & 0.10 & 0.10 & 0.10 & 0.10 & 0.10 \\
\hline L-Lysine, $76.8 \%$ & 0.01 & 0.05 & 0.09 & 0.13 & 0.18 & 0.22 \\
\hline L-Methionine, 57.4\% & 0.07 & 0.07 & 0.07 & 0.07 & 0.07 & 0.07 \\
\hline Salt & 0.40 & 0.40 & 0.40 & 0.40 & 0.40 & 0.40 \\
\hline Vitamin premix ${ }^{3)}$ & 0.03 & 0.03 & 0.03 & 0.03 & 0.03 & 0.03 \\
\hline Trace mineral premix ${ }^{4)}$ & 0.50 & 0.50 & 0.50 & 0.50 & 0.50 & 0.50 \\
\hline Total & 100.00 & 100.00 & 100.00 & 100.00 & 100.00 & 100.00 \\
\hline \multicolumn{7}{|l|}{ Calculated energy and nutrient composition } \\
\hline Digestible energy $(\mathrm{kJ} / \mathrm{g})$ & 14.25 & 14.21 & 14.21 & 14.17 & 14.12 & 14.15 \\
\hline Crude protein (\%) & 16.88 & 16.84 & 16.87 & 16.89 & 16.89 & 16.87 \\
\hline Crude fat (\%) & 6.07 & 6.07 & 6.07 & 6.08 & 6.08 & 6.08 \\
\hline Lysine (\%) & 1.07 & 1.08 & 1.07 & 1.10 & 1.07 & 1.07 \\
\hline Methionine (\%) & 0.39 & 0.37 & 0.36 & 0.39 & 0.36 & 0.39 \\
\hline Threonine (\%) & 0.54 & 0.55 & 0.54 & 0.56 & 0.57 & 0.55 \\
\hline Tryptopan (\%) & 0.16 & 0.16 & 0.16 & 0.16 & 0.16 & 0.16 \\
\hline $\mathrm{Ca}(\%)$ & 0.82 & 0.83 & 0.83 & 0.83 & 0.83 & 0.83 \\
\hline Available P (\%) & 0.54 & 0.55 & 0.55 & 0.56 & 0.56 & 0.57 \\
\hline Phorbol esters (mg/kg) & 0.00 & 2.75 & 5.50 & 8.25 & 11.00 & 13.75 \\
\hline
\end{tabular}

1) DJM0, DJM15, DJM30, DJM45, DJM60, and DJM75 were diets in which the detoxified Jatropha curcas kernel meal was included in the diets to replace 0\%, 15\%, 30\%, $45 \%, 60 \%$, and $75 \%$ soybean meal, respectively.

${ }^{2)}$ Content of crude protein ( $\mathrm{g} / \mathrm{kg}$ ): soybean meal 442; detoxified Jatropha curcas kernel meal 580; fish meal 535.

3) Provided per kilogram of complete diet: vitamin $A, 10,500 \mathrm{IU}$; vitamin $\mathrm{D}_{3}, 3,000 \mathrm{IU}$; vitamin $\mathrm{E}, 22.5 \mathrm{IU}$; vitamin $\mathrm{K}_{3}, 3$ mg; vitamin $\mathrm{B}_{1}, 3 \mathrm{mg} ;$ vitamin $\mathrm{B}_{2}, 7.5 \mathrm{mg}$; vitamin $\mathrm{B}_{6}, 4.5$ $\mathrm{mg}$; vitamin $\mathrm{B}_{12}, 0.03 \mathrm{mg}$; niacin, $30 \mathrm{mg}$; calcium pantothenate, $15 \mathrm{mg}$; folic acid, $1.5 \mathrm{mg}$; biotin, $0.12 \mathrm{mg}$.

4) Provided per kilogram of complete diet: $20 \mathrm{mg}$ of $\mathrm{Cu}$ as $\mathrm{CuSO}_{4} ; 150 \mathrm{mg}$ of Fe as $\mathrm{FeSO}_{4} ; 0.3 \mathrm{mg}$ of I as Kl; $150 \mathrm{mg}$ of Zn as ZnSO${ }_{4} ; 30 \mathrm{mg}$ of $\mathrm{Mn}^{2}$ as $\mathrm{MnSO}_{4} ; 0.3 \mathrm{mg}$ of $\mathrm{Se}^{2}$ as $\mathrm{Na}_{2} \mathrm{SeO}_{3}$. 
Table 3. Ingredients and chemical composition of the different diets to growing pigs for 50 to $80 \mathrm{~kg}$ (as fed basis)

\begin{tabular}{|c|c|c|c|c|c|c|}
\hline \multirow{2}{*}{ Item } & \multicolumn{6}{|c|}{ Dietary treatments ${ }^{1)}$} \\
\hline & DJM0 & DJM15 & DJM30 & DJM45 & DJM60 & DJM75 \\
\hline \multicolumn{7}{|l|}{ Ingredients (\%) } \\
\hline Soybean meal $\left.\right|^{2)}$ & 22.36 & 18.87 & 15.41 & 11.99 & 8.58 & 5.07 \\
\hline Wheat middings & 8.00 & 7.50 & 7.00 & 6.20 & 5.56 & 5.34 \\
\hline Detoxified Jatropha curcas kernel meal' ${ }^{2)}$ & 0.00 & 2.50 & 5.00 & 7.50 & 10.00 & 12.50 \\
\hline Monocalcium phosphate & 0.37 & 0.38 & 0.4 & 0.43 & 0.45 & 0.47 \\
\hline Salt & 0.40 & 0.40 & 0.40 & 0.40 & 0.40 & 0.40 \\
\hline L-Methionine, 57.4\% & 0.07 & 0.07 & 0.07 & 0.07 & 0.07 & 0.07 \\
\hline L-Lysine, 76.8\% & 0.21 & 0.26 & 0.30 & 0.35 & 0.39 & 0.43 \\
\hline L-Threonine, $71.8 \%$ & 0.10 & 0.10 & 0.10 & 0.10 & 0.10 & 0.11 \\
\hline \multicolumn{7}{|l|}{ Calculated energy and nutrient composition } \\
\hline Digestible energy $(\mathrm{kJ} / \mathrm{g})$ & 13.38 & 13.39 & 13.40 & 13.38 & 13.38 & 13.39 \\
\hline Crude protein (\%) & 16.50 & 16.50 & 16.50 & 16.50 & 16.51 & 16.51 \\
\hline Crude fat (\%) & 3.08 & 3.08 & 3.08 & 3.07 & 3.07 & 3.07 \\
\hline Lysine (\%) & 0.89 & 0.86 & 0.88 & 0.84 & 0.86 & 0.86 \\
\hline Methionine (\%) & 0.31 & 0.34 & 0.33 & 0.31 & 0.34 & 0.31 \\
\hline Threonine (\%) & 0.62 & 0.62 & 0.60 & 0.61 & 0.61 & 0.63 \\
\hline Tryptopan (\%) & 0.16 & 0.16 & 0.16 & 0.16 & 0.16 & 0.16 \\
\hline $\mathrm{Ca}(\%)$ & 0.52 & 0.51 & 0.52 & 0.51 & 0.51 & 0.51 \\
\hline Available P (\%) & 0.21 & 0.21 & 0.21 & 0.21 & 0.21 & 0.21 \\
\hline
\end{tabular}

1) DJM0, DJM15, DJM30, DJM45, DJM60, and DJM75 were diets in which the detoxified Jatropha curcas kernel meal was included in the diets to replace 0\%, 15\%, 30\%, $45 \%, 60 \%$, and $75 \%$ soybean meal, respectively.

${ }^{2)}$ Content of crude protein $(\mathrm{g} / \mathrm{kg})$ : soybean meal 442; detoxified Jatropha curcas kernel meal 580.

${ }^{3)}$ Provided per kilogram of complete diet: vitamin $\mathrm{A}, 10,500 \mathrm{IU}$; vitamin $\mathrm{D}_{3}, 3,000 \mathrm{IU}$; vitamin $\mathrm{E}, 22.5 \mathrm{IU}$; vitamin $\mathrm{K}_{3}, 3 \mathrm{mg}$; vitamin $\mathrm{B}_{1}, 3 \mathrm{mg}$; vitamin $\mathrm{B}_{2}, 7.5 \mathrm{mg}$; vitamin $\mathrm{B}_{6}, 4.5$ $\mathrm{mg}$; vitamin $\mathrm{B}_{12}, 0.03 \mathrm{mg}$; niacin, $30 \mathrm{mg}$; calcium pantothenate, $15 \mathrm{mg}$; folic acid, $1.5 \mathrm{mg}$; biotin, $0.12 \mathrm{mg}$.

4) Provided per kilogram of complete diet: $20 \mathrm{mg}$ of $\mathrm{Cu}$ as $\mathrm{CuSO}_{4} ; 150 \mathrm{mg}$ of Fe as $\mathrm{FeSO}_{4} ; 0.3 \mathrm{mg}$ of I as Kl; $150 \mathrm{mg}$ of $\mathrm{Zn}$ as $\mathrm{ZnSO}_{4} ; 30 \mathrm{mg}$ of $\mathrm{Mn}^{2}$ as $\mathrm{MnSO}_{4} ; 0.3 \mathrm{mg}$ of $\mathrm{Se}^{2}$ as $\mathrm{Na}_{2} \mathrm{SeO}_{3}$.

\section{Sampling procedure}

At the end of 79-d study, a total of 36 pigs, 6 for each treatment close to the average weight in each group, were slaughtered to examine the small intestine. Small intestine was dissected and measured for weight and length quickly after evisceration. The small intestine in growing pigs was defined as the portion of the digestive tract between the pylorus and the ileocecal junction and intestinal segments (duodenum, jejunum, and ileum) were obtained by using the anatomical landmarks, with pyloric-duodenal junction to duodenal-jejunal junction being duodenum, duodenal-jejunal junction to jejunal-ileal junction being jejunum, and jejunal-ileal junction to ileocecal junction being ileum [18]. The relative weight (intestinal weight/body weight) was calculated as the intestinal weight divided by body weight, and the intestinal index (weight/length) was calculated as the intestinal weight divided by the intestine length. Besides, the segments (about $2 \mathrm{~cm}$ ) of tissues from duodenum, jejunum and ileum were taken for morphological examination, and then immediately rinsed by physiological saline, fixed overnight in $10 \%$ neutral formalin for $24 \mathrm{~h}$ prepared to make pathological tissue section. The intestinal mucosal of remaining jejunum was scraped off carefully with a glass slide, snap frozen in liquid nitrogen and then stored in $-80^{\circ} \mathrm{C}$ for future analyses. In addition, $50 \mathrm{~g}$ sample of muscle tissues (longissimus, psoas major, and semitendinosus) per pig were taken to detect the content of residual PEs.

\section{Mucosal morphology measurements}

After the intestinal segments (duodenum, jejunum, and ileum) were fixed in $10 \%$ neutral formalin fixative for $24 \mathrm{~h}$, they were treated following the dehydration, clearing and paraffin embedding procedures. Then serial sections of $5 \mu \mathrm{m}$ thickness were made for histopathological studies, followed by straining with hematoxylin and eosin stain. The samples were examined 
by microscopy later. Two transverse sections of each duodenum, jejunum, or ileum samples were prepared on one slide for morphometric analysis. A total of 12 to 20 intact, welloriented crypt-villus units per sample were selected randomly and measured. Villus height was measured from the tip of the villus to the base between individual villus, and crypt depth measurements were taken from the valley between individual villus to the basal membrane. Images of the sections were captured at the magnification of $100 \times$ using an Olympus BX51 microscope equipped with a DP70 digital camera (Olympus, Tokyo, Japan). Crypt depth $(\mu \mathrm{m})$ and villus height $(\mu \mathrm{m})$ in the small intestine were measured with JD801 morphologic image analysis software, and then villus height/crypt depth (V/C) calculated as the villus height divided by the crypt depth.

\section{Enzyme activity}

Activities of brush border enzymes were determined in jejunum mucosa. After thawing, $0.5 \mathrm{~g}$ of mucosal scraping was homogenized with ice-cold physiological saline and centrifuged for $15 \mathrm{~min}$ at $3,000 \times \mathrm{g}$ at $4^{\circ} \mathrm{C}$. The activities of protease, amylase, lipase, and trypsin were measured by kits according to the instructions of manufacturer (Jiancheng Bioengineering Ltd, Nanjing, China).

\section{Determination of anti-nutritional factors and phorbol esters}

Trypsin inhibitors activities in DJM were determined according to Smith et al [19] and Liu and Markakis [20]. Ground DJM samples ( $0.25 \mathrm{~g}$ each) were extracted in $12.5 \mathrm{~mL}$ of 0.01 $\mathrm{M} \mathrm{NaOH}$ at $\mathrm{pH} 9.4$ to 9.6 using an ultra-turrax $(20,000 \mathrm{rpm}$ for $5 \mathrm{~min}$ ) with intermittent cooling. The supernatants were collected after being centrifuged at 3,500×g for $15 \mathrm{~min}$ and then centrifuged a second time at $9,500 \times \mathrm{g}$. The supernatants were collected and used for the assay after appropriate dilution with distilled water. The results are expressed as mg trypsin inhibited per $g$ of sample.

The lectin content in DJM was analyzed by haemagglutination assay [7]. Ground DJM samples (2 $\mathrm{g}$ each) were extracted in $10 \mathrm{~mL}$ of phosphate-buffered saline using an ultra-turrax (20,000 rpm for $5 \mathrm{~min}$ ) with intermittent $5 \mathrm{~min}$ cooling using an ice bath. The contents were filtered through No. 540 filter paper and the filtrate was collected. The solution was mixed, and the sedimentation pattern of the erythrocyte suspensions were read after $2 \mathrm{~h}$ at room temperature. The haemagglutination activity was defined as the minimum amount of meal in $\mathrm{mg}$ per $\mathrm{mL}$ of assay medium which produced agglutination.

The residual PEs in the DJM and muscle tissues were detected by high-performance liquid chromatography (HPLC) according to the methods of Makkar et al [7] and Makkar et $\mathrm{al}$ [21]. In short, $0.5 \mathrm{~g}$ of DJM and dried muscle sample were extracted four times with methanol. An aliquot $(20 \mu \mathrm{L})$ was loaded on a HPLC reverse-phase C18LiChrospher 100, $5 \mu \mathrm{m}$
(250×4.6 mm inside dimensions from Merck, Darmstadt, Germany) column. The separation was performed at $22^{\circ} \mathrm{C}$ and the flow rate was $1.3 \mathrm{~mL} / \mathrm{min}$ using a gradient elution. The PEs peaks were detected at $280 \mathrm{~nm}$ and appeared between 18.0 to $19.5 \mathrm{~min}$. The results were expressed as equivalent to a standard, phorbor-12-myristate 13-acetate. The detection limit of PEs is $3 \mu \mathrm{g} / \mathrm{g}$ samples.

\section{Chemical analyses and calculation}

Feces and urine were collected per pig and enclosed in a container with $5 \% \mathrm{H}_{2} \mathrm{SO}_{4}$ at the bottom daily during 6-d period. Subsequently, the samples of feces and urine were stored at $-20^{\circ} \mathrm{C}$ and $4^{\circ} \mathrm{C}$, respectively. At the end of the period, feces were natural thawed, pooled over successive days, and weighted, homogenized, subsampled and heat-dried for chemical analyses. Similarly, urine was pooled, weighted, homogenized and subsampled for chemical analyses. Samples of feces and urine were analyzed for nitrogen content determined by the Kjeldahl method using a Kjeltec 8400 Analyzer Unit (Foss, Sweden) and gross energy with an Parr 1281 isoperibol bomb calorimeter (Parr Instrument Company, Moline, IL, USA). Nitrogen deposition (ND) of each pig was obtained as the difference between nitrogen intake (NI) and nitrogen losses in the feces (NF) and urine (NU). Digestible energy was determined as the difference between gross energy (GE) and fecal energy (FE). The digestibility of nitrogen (DN), total nitrogen utilization (TNU), biological value (BV), and energy digestibility (ED) were calculated as indicated below [22]:

$$
\begin{aligned}
& \text { Digestibility of nitrogen }(\%)=[(\mathrm{NI}-\mathrm{NF}) / \mathrm{NI}] \times 100 \\
& \text { Total nitrogen utilization }(\%)=[(\mathrm{NI}-\mathrm{NF}-\mathrm{NU}) / \mathrm{NI}] \times 100
\end{aligned}
$$$$
\text { Biological value }(\%)=\{[\mathrm{NI}-(\mathrm{NF}+\mathrm{NU})] /(\mathrm{NI}-\mathrm{NF})\} \times 100
$$

Energy digestibility $(\%)=[(\mathrm{GE}-\mathrm{FE}) / \mathrm{GE}] \times 100$

\section{Statistical analyses}

The average pen data were used to evaluate effects on growth performance and the pig was considered as the experimental unit for all other variables using the general linear model procedures of SAS (9.0 Inst., Inc., Cary, NC, USA). Variations among the 6 treatments were compared with each other using Duncan's multiple comparisons. Preplanned single degree of freedom comparisons were also made to measure the linear and quadratic effects of the replacement of SBM by DJM. Values are expressed as means with standard error of the mean. Differences between treatments were considered significant when $\mathrm{p}<0.05$.

\section{RESULTS}


Proximate composition, anti-nutrients and amino acid profile in DJM

Proximate composition, anti-nutrients and amino acid profile in DJM are shown in Table 1. The content of CP was 580 $\mathrm{g} / \mathrm{kg}$, and the gross energy was $13.19 \mathrm{~kJ} / \mathrm{g}$. The content of PEs was $0.11 \mathrm{mg} / \mathrm{g}$, and trypsin inhibitor activity and lectin were not detected in DJM samples.

\section{Growth performance}

For all trial periods, increasing replacement of SBM with DJM decreased body weight, ADG, ADFI, and G:F of pigs (linear, $\mathrm{p}<0.01$; quadratic, $\mathrm{p}<0.01$; Table 4 ) with pigs fed DJM45, DJM60, and DJM75 gaining lower body weight, ADG, ADFI, and G:F than pigs fed DJM0 $(\mathrm{p}<0.05)$.

\section{Diarrhea morbidity and mortality}

During the experiment period, the highest diarrhea morbidity (Table 4) was observed in DJM75, which was significantly not different from those in DJM30, DJM45, and DJM60 but was higher $(\mathrm{p}<0.05)$ than those in DJM0 and DJM15, and only one pig from DJM75 died from serious diarrhea. Diarrhea morbidity demonstrated linear and quadratic effects $(p<0.01)$ in response to increasing replacement of SBM with DJM.

\section{Digestive utilization of dietary protein and energy}

Effect of replacing SBM by DJM in the diet on digestive utilization of dietary protein and energy of growing pigs is shown in Table 5. The ND, DN, ED, and TNU of growing pigs were linearly $(p<0.05)$ and quadratically $(p<0.05)$ decreased with increasing replacement of SBM with DJM, but those were not significantly reduced in DJM15 and DJM30 compared with DJM0. No marked difference in BV and digestible energy were observed among all treatments.

\section{Intestinal development}

Effect of replacing SBM with DJM in the diets on nutrient utilization of growing pigs is shown in Table 6. Increasing the replacement of SBM with DJM decreased the duodenum weight (linear, $p<0.01$; quadratic, $p=0.01$ ) and ileum weight (linear, $\mathrm{p}<0.01$; quadratic, $\mathrm{p}<0.01$ ). The ileum length in DJM15 showed highest among all treatments and significantly higher than that in DJM75 ( $\mathrm{p}=0.03)$. The other indexes were not affected by the replacement of SBM with DJM.

Table 4. Effect of replacing soybean meal protein with detoxified Jatropha curcas kernel meal in the diets on growth performance and diarrhea morbidity of growing pigs

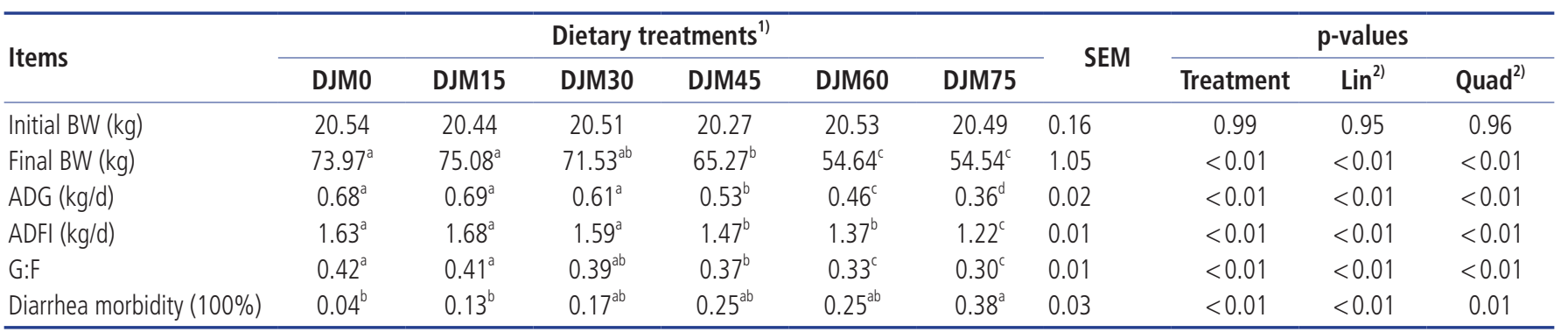

SEM, standard error of the mean; BW, body weight; $A D G$, average daily gain; $A D F I$, average daily feed intake; G:F, gain-to-feed ratio.

1) DJM0, DJM15, DJM30, DJM45, DJM60, and DJM75 were diets in which the detoxified Jatropha curcas kernel meal was included in the diets to replace $0 \%$, 15\%, 30\%, $45 \%, 60 \%$, and $75 \%$ soybean meal with phorbol esters concentration $0,2.75,5.50,8.25,11.00$, and $13.75 \mathrm{mg} / \mathrm{kg}$ diet, respectively.

${ }^{2)} \mathrm{Lin}$ and quad, linear and quadratic effect of the replacement of soybean protein with different levels of detoxified Jatropha curcas kernel meal in growing pig diets.

a-c Means with different superscripts within a row differ $(p<0.05)$.

Table 5. Effect of replacing soybean meal with detoxified Jatropha curcas kernel meal in the diets on nutrient utilization of growing pigs

\begin{tabular}{|c|c|c|c|c|c|c|c|c|c|c|}
\hline \multirow{2}{*}{ Items } & \multicolumn{6}{|c|}{ Dietary treatments ${ }^{1)}$} & \multirow{2}{*}{ SEM } & \multicolumn{3}{|c|}{ p-values } \\
\hline & DJM0 & DJM15 & DJM30 & DJM45 & DJM60 & DJM75 & & Treatment & $\operatorname{Lin}^{2)}$ & Quad $^{2}$ \\
\hline$N D(g / d)$ & $177.72^{a}$ & $176.96^{\mathrm{a}}$ & $165.19^{\mathrm{ab}}$ & $138.06^{b}$ & $130.86^{b}$ & $101.15^{c}$ & 9.99 & $<0.01$ & $<0.01$ & $<0.01$ \\
\hline DN (100\%) & $67.88^{\mathrm{a}}$ & $67.67^{\mathrm{a}}$ & $62.57^{\mathrm{a}}$ & $53.30^{b}$ & $52.49^{b}$ & $51.10^{b}$ & 2.22 & $<0.01$ & $<0.01$ & 0.03 \\
\hline TNU (100\%) & $10.83^{\mathrm{a}}$ & $10.15^{\mathrm{a}}$ & $9.81^{a}$ & $8.50^{b}$ & $8.35^{b}$ & $8.07^{b}$ & 0.37 & $<0.01$ & $<0.01$ & $<0.01$ \\
\hline BV (100\%) & 95.73 & 95.17 & 95.63 & 95.71 & 95.37 & 94.66 & 0.55 & 0.73 & 0.22 & 0.26 \\
\hline $\mathrm{DE}(\mathrm{MJ} / \mathrm{d})$ & 11.23 & 12.20 & 11.29 & 10.94 & 12.35 & 9.04 & 0.66 & 0.06 & 0.33 & 0.38 \\
\hline ED (100\%) & $88^{a}$ & $87^{\mathrm{a}}$ & $85^{\mathrm{ab}}$ & $83^{b}$ & $82^{b}$ & $84^{b}$ & 1.32 & $<0.01$ & 0.03 & 0.04 \\
\hline
\end{tabular}

SEM, standard error of the mean; ND, nitrogen deposition; DN, digestibility of nitrogen; TNU, total nitrogen utilization; BV, biological value; DE, digestible energy; ED, energy digestibility.

1) DJM0, DJM15, DJM30, DJM45, DJM60, and DJM75 were diets in which the detoxified Jatropha curcas kernel meal was included in the diets to replace $0 \%$, 15\%, 30\%, $45 \%, 60 \%$, and $75 \%$ soybean meal with phorbol esters concentration $0,2.75,5.50,8.25,11.00$, and $13.75 \mathrm{mg} / \mathrm{kg}$ diets, respectively.

${ }^{2)}$ Lin and quad, linear and quadratic effect of the replacement of soybean protein with different levels of detoxified Jatropha curcas kernel meal in growing pig diets.

${ }^{a-c}$ Means with different superscripts within a row differ $(p<0.05)$. 
Table 6. Effect of replacing soybean meal with detoxified Jatropha curcas kernel meal in the diets on intestinal development of growing pigs

\begin{tabular}{|c|c|c|c|c|c|c|c|c|c|c|}
\hline \multirow{2}{*}{ Items } & \multicolumn{6}{|c|}{ Dietary treatments ${ }^{1)}$} & \multirow{2}{*}{ SEM } & \multicolumn{3}{|c|}{ p-value } \\
\hline & DJM0 & DJM15 & DJM30 & DJM45 & DJM60 & DJM75 & & Treatment & $\operatorname{Lin}^{2)}$ & Quad $^{2}$ \\
\hline \multicolumn{11}{|l|}{ Duodenum } \\
\hline Weight (g) & $77^{\mathrm{ab}}$ & $93^{\mathrm{a}}$ & $81^{\mathrm{ab}}$ & $69^{b c}$ & $57^{c}$ & $57^{c}$ & 2.19 & $<0.01$ & $<0.01$ & 0.01 \\
\hline Length $(\mathrm{cm})$ & 58 & 57 & 57 & 60 & 53 & 47 & 1.51 & 0.20 & 0.06 & 0.04 \\
\hline Relative weight ${ }^{3)}$ (g/kg BW) & $1.10^{\mathrm{ab}}$ & $1.34^{\mathrm{a}}$ & $1.18^{\mathrm{ab}}$ & $1.15^{\mathrm{ab}}$ & $0.98^{b}$ & $1.33^{\mathrm{a}}$ & 0.03 & 0.02 & 0.96 & 0.83 \\
\hline Intestinal index $x^{3)}(\mathrm{g} / \mathrm{cm})$ & 1.32 & 1.62 & 1.43 & 1.17 & 1.08 & 1.24 & 0.05 & 0.06 & 0.05 & 0.15 \\
\hline \multicolumn{11}{|l|}{ Jejunum } \\
\hline Weight (g) & 1,564 & 1,546 & 1,611 & 1,470 & 1,524 & 1,413 & 62.65 & 0.20 & 0.42 & 0.68 \\
\hline Length $(\mathrm{cm})$ & 1,855 & 1,857 & 1,904 & 1,937 & 1,681 & 1,783 & 56.32 & 0.81 & 0.44 & 0.63 \\
\hline Relative weight ${ }^{3)}$ (g/kg BW) & 22.46 & 22.52 & 23.41 & 24.57 & 26.18 & 34.60 & 1.65 & 0.30 & 0.05 & 0.06 \\
\hline Intestinal index ${ }^{3)}(\mathrm{g} / \mathrm{cm})$ & 0.84 & 0.83 & 0.85 & 0.77 & 0.95 & 0.79 & 0.04 & 0.85 & 0.99 & 0.99 \\
\hline \multicolumn{11}{|l|}{ lleum } \\
\hline Weight (g) & $79^{\mathrm{ab}}$ & $83^{\mathrm{a}}$ & $73^{\mathrm{ab}}$ & $60^{\mathrm{abc}}$ & $45^{c}$ & $40^{c}$ & 3.62 & 0.01 & $<0.01$ & $<0.01$ \\
\hline Length $(\mathrm{cm})$ & $56^{\mathrm{ab}}$ & $70^{\mathrm{a}}$ & $67^{\mathrm{a}}$ & $40^{\mathrm{ab}}$ & $33^{b}$ & $29^{b}$ & 3.90 & 0.03 & 0.03 & $<0.01$ \\
\hline Relative weight ${ }^{3)}$ (g/kg BW) & 1.13 & 1.23 & 1.05 & 0.98 & 0.77 & 0.95 & 0.06 & 0.33 & 0.05 & 0.16 \\
\hline Intestinal index $(\mathrm{g} / \mathrm{cm})$ & 1.48 & 1.20 & 1.13 & 1.45 & 1.34 & 1.38 & 0.05 & 0.28 & 0.81 & 0.45 \\
\hline
\end{tabular}

SEM, standard error of the mean; BW, body weight.

1) DJMO, DJM15, DJM30, DJM45, DJM60 and DJM75 were diets in which the detoxified Jatropha curcas kernel meal was included in the diets to replace $0 \%, 15 \%, 30 \%$, $45 \%, 60 \%$, and $75 \%$ soybean meal with phorbol esters concentration $0,2.75,5.50,8.25,11.00$, and $13.75 \mathrm{mg} / \mathrm{kg}$ diet, respectively.

2) $L$ in and quad, linear and quadratic effect of the replacement of soybean protein with different levels of detoxified Jatropha curcas kernel meal in growing pig diets.

${ }^{3)}$ Relative weight was calculated as the intestinal weight divided by body weight, and intestinal index was calculated as the intestinal weight divided by the intestine length.

${ }^{a-c}$ Means with different superscripts within a row differ $(p<0.05)$.

\section{Intestinal morphology}

The results of morphometric measurements in duodenum, jejunum, and ileum of growing pigs are shown in Table 7. The villus height of duodenum was deceased as the replacement of SBM with DJM increased (linear, $\mathrm{p}<0.01$; quadratic, $\mathrm{p}=0.02$ ). The villus heights of jejunum were not affected by the replacement of SBM with DJM. The V/C of jejunum showed a linear decrease with the replacement of SBM with DJM increasing $(\mathrm{p}=0.01)$. Meanwhile, villi of jejunum in DJM75 showed changes such as shorter, disorder and breaking compared with that in DJM0 (Figure 1). No significant decrease was observed in all measured indicates when the replacement was $15 \%$ or $30 \%$.

Table 7. Effect of replacing soybean meal with detoxified Jatropha curcas kernel meal in the diets on morphometric measurements in duodenum, jejunum and ileum of growing pigs

\begin{tabular}{|c|c|c|c|c|c|c|c|c|c|c|}
\hline \multirow{2}{*}{ Items } & \multicolumn{6}{|c|}{ Dietary treatments ${ }^{1)}$} & \multirow{2}{*}{ SEM } & \multicolumn{3}{|c|}{ p-value } \\
\hline & DJMO & DJM15 & DJM30 & DJM45 & DJM60 & DJM75 & & Treatment & $\operatorname{Lin}^{2)}$ & Quad $^{2)}$ \\
\hline \multicolumn{11}{|l|}{ Duodenum } \\
\hline Villus height ( $\mu \mathrm{m})$ & $169.57^{a}$ & $147.14^{\mathrm{ab}}$ & $145.35^{a b}$ & $110.73^{b c}$ & $109.98^{b c}$ & $102.86^{c}$ & 6.93 & $<0.01$ & $<0.01$ & 0.02 \\
\hline Crypt depth ( $\mu m)$ & 223.65 & 233.33 & 263.04 & 175.74 & 212.95 & 250.95 & 11.32 & 0.09 & 0.97 & 0.89 \\
\hline Villus/crypt ratio & 0.76 & 0.67 & 0.56 & 0.65 & 0.52 & 0.42 & 0.03 & 0.06 & 0.01 & 0.07 \\
\hline \multicolumn{11}{|l|}{ Jejunum } \\
\hline Villus height ( $\mu \mathrm{m})$ & $165.53^{a}$ & $159.42^{a}$ & $150.12^{a b}$ & $121.73^{b c}$ & $113.82^{c}$ & $98.79^{c}$ & 6.06 & 0.01 & 0.07 & 0.14 \\
\hline Crypt depth $(\mu m)$ & 200.53 & 204.55 & 198.32 & 236.45 & 198.13 & 217.3 & 7.84 & 0.55 & 0.48 & 0.77 \\
\hline Villus/crypt ratio & $0.83^{\mathrm{a}}$ & $0.78^{\mathrm{ab}}$ & $0.77^{\mathrm{ab}}$ & $0.52^{c}$ & $0.61^{b c}$ & $0.43^{c}$ & 0.05 & $<0.01$ & 0.01 & 0.07 \\
\hline \multicolumn{11}{|l|}{ lleum } \\
\hline Villus height ( $\mu \mathrm{m})$ & 137.18 & 155.68 & 149.64 & 126.35 & 132.59 & 130.56 & 8.23 & 0.89 & 0.23 & 0.48 \\
\hline Crypt depth ( $\mu m)$ & 159.92 & 176.85 & 150.87 & 199.98 & 202.01 & 166.49 & 10.84 & 0.68 & 0.43 & 0.61 \\
\hline Villus/crypt ratio & 0.85 & 0.89 & 0.98 & 0.63 & 0.77 & 0.84 & 0.05 & 0.53 & 0.61 & 0.41 \\
\hline
\end{tabular}

SEM, standard error of the mean.

1) DJM0, DJM15, DJM30, DJM45, DJM60 and DJM75 were diets in which the detoxified Jatropha curcas kernel meal was included in the diets to replace $0 \%, 15 \%, 30 \%$, $45 \%, 60 \%$, and $75 \%$ soybean meal with phorbol esters concentration $0,2.75,5.50,8.25,11.00$, and $13.75 \mathrm{mg} / \mathrm{kg}$ diets, respectively.

${ }^{2)}$ Lin and quad, linear and quadratic effect of the replacement of soybean protein with different levels of detoxified Jatropha curcas kernel meal in growing pig diets.

${ }^{a-c}$ Means with different superscripts within a row differ $(p<0.05)$. 

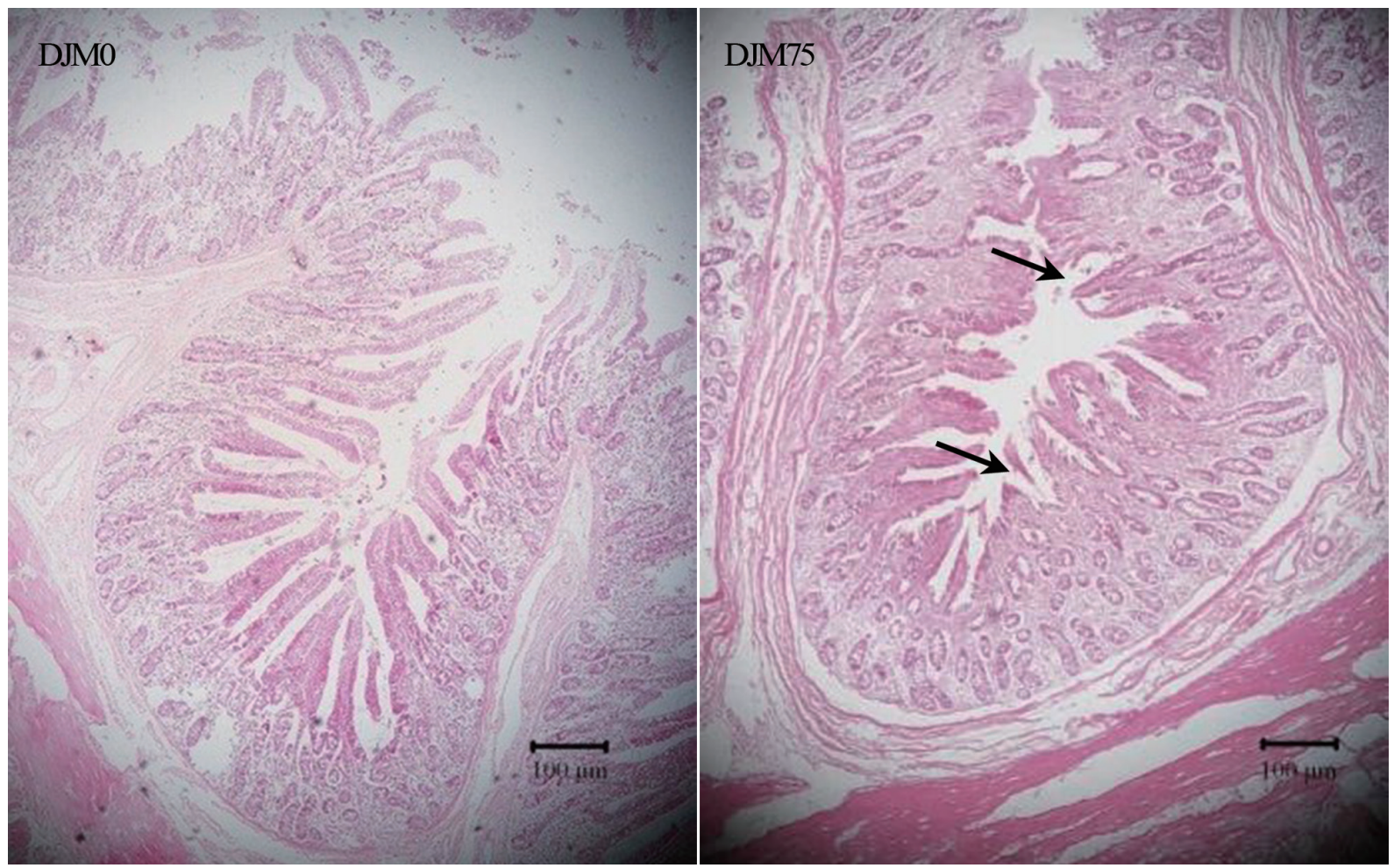

Figure 1. Jejunum morphology of growing pigs. DJM0 and DJM75 were diets in which the detoxified Jatropha curcas kernel meal (DJM) was included in the diets to replace $0 \%$ and $75 \%$ soybean meal with phorbol esters concentration 0 and $13.75 \mathrm{mg} / \mathrm{kg}$ diet, respectively. Intestinal villi of diet DJM75 were shorter compared with that of diet DJM0, and showed changes such as disorder and breaking. 100x magnification.

\section{Enzyme activities}

Effect of replacing SBM by DJM in the diets on enzyme activities in jejunum of growing pigs was shown in Table 8 . There were linear $(\mathrm{p}<0.01)$ and quadratic $(\mathrm{p}<0.01)$ effects of different SBM replacements with DJM on the protease, amylase, lipase, and trypsin activities with no significant reduced activities when the replacement was $15 \%$ or $30 \%$.

\section{The content of residual phorbol esters in muscles}

No PE was detected in the 25 samples of longissimus, psoas major, and semitendinosus (5 samples in each treatment) in DJM15, DJM30, DJM45, DJM60, and DJM75 (Figure 2).

\section{DISCUSSION}

Many researches showed that DJM was a good protein resource to replace a certain amount of SBM for animals [23]. The crude protein of DJM was higher than SBM, and the levels of essential amino acids except lysine in Jatropha curcas kernel meal were higher than that for the FAO reference protein [10], which were similar with the results from our study. Besides, the pigs fed DJM diets where the replacement was less than $30 \%$ showed good ADFI, ADG, and G:F, especially with $15 \%$ of replacement, demonstrating the nutritive potential of DJM as a protein source in pig feed. However, when the replacement of SBM by DJM was over than $30 \%$, lower ADFI, ADG,

Table 8. Effect of replacing soybean meal with detoxified Jatropha curcas kernel meal in the diets on enzyme activities in jejunum of growing pigs

\begin{tabular}{|c|c|c|c|c|c|c|c|c|c|c|}
\hline \multirow{2}{*}{ Items $^{2)}$} & \multicolumn{6}{|c|}{ Dietary treatments ${ }^{1)}$} & \multirow{2}{*}{ SEM } & \multicolumn{3}{|c|}{$p$-values } \\
\hline & DJMO & DJM15 & DJM30 & DJM45 & DJM60 & DJM75 & & Treatment & $\operatorname{Lin}^{3)}$ & Quad $^{3)}$ \\
\hline Protease & $48.47^{\mathrm{a}}$ & $48.74^{\mathrm{a}}$ & $47.01^{\mathrm{a}}$ & $42.16^{b}$ & $38.42^{b}$ & $31.10^{c}$ & 0.68 & $<0.01$ & $<0.01$ & $<0.01$ \\
\hline Amylase & $1,100.09^{a}$ & $1,093.02^{a}$ & $1,040.93^{\mathrm{ab}}$ & $947.03^{b c}$ & $845.90^{\mathrm{cd}}$ & $794.21^{d}$ & 14.48 & $<0.01$ & $<0.01$ & $<0.01$ \\
\hline Lipase & $7.76^{\mathrm{a}}$ & $7.80^{\mathrm{a}}$ & $7.24^{\mathrm{ab}}$ & $6.71^{\mathrm{ab}}$ & $6.07^{b}$ & $5.81^{b}$ & 0.20 & 0.03 & $<0.01$ & $<0.01$ \\
\hline Trypsin & $87.56^{\mathrm{a}}$ & $87.45^{\mathrm{a}}$ & $81.92^{\mathrm{ab}}$ & $76.41^{b}$ & $70.20^{c}$ & $67.59^{c}$ & 1.23 & $<0.01$ & $<0.01$ & $<0.01$ \\
\hline
\end{tabular}

1) DJM0, DJM15, DJM30, DJM45, DJM60 and DJM75 were diets in which the detoxified Jatropha curcas kernel meal was included in the diets to replace 0\%, 15\%, 30\%, $45 \%, 60 \%$, and $75 \%$ soybean meal with phorbol esters concentration $0,2.75,5.50,8.25,11.00$, and $13.75 \mathrm{mg} / \mathrm{kg}$ diets, respectively.

${ }^{2)}$ Digestive enzyme activities in the small intestinal contents are expressed as $\mathrm{U} / \mathrm{mg}$ protein.

${ }^{3)}$ Lin and quad, linear and quadratic effect of the replacement of soybean protein with different levels of detoxified Jatropha curcas kernel meal in growing pig diets.

${ }^{a-d}$ Means with different superscripts within a row differ $(p<0.05)$. 


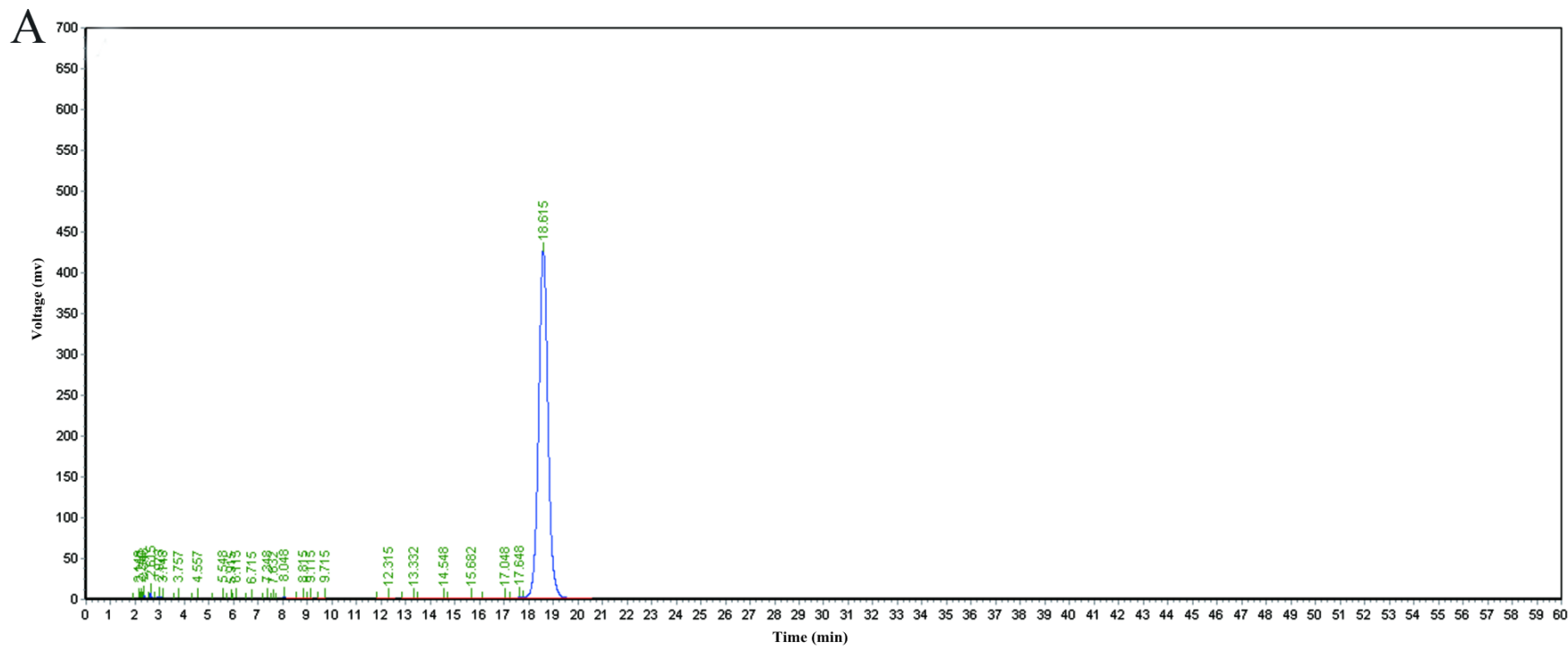

$\mathrm{B}$

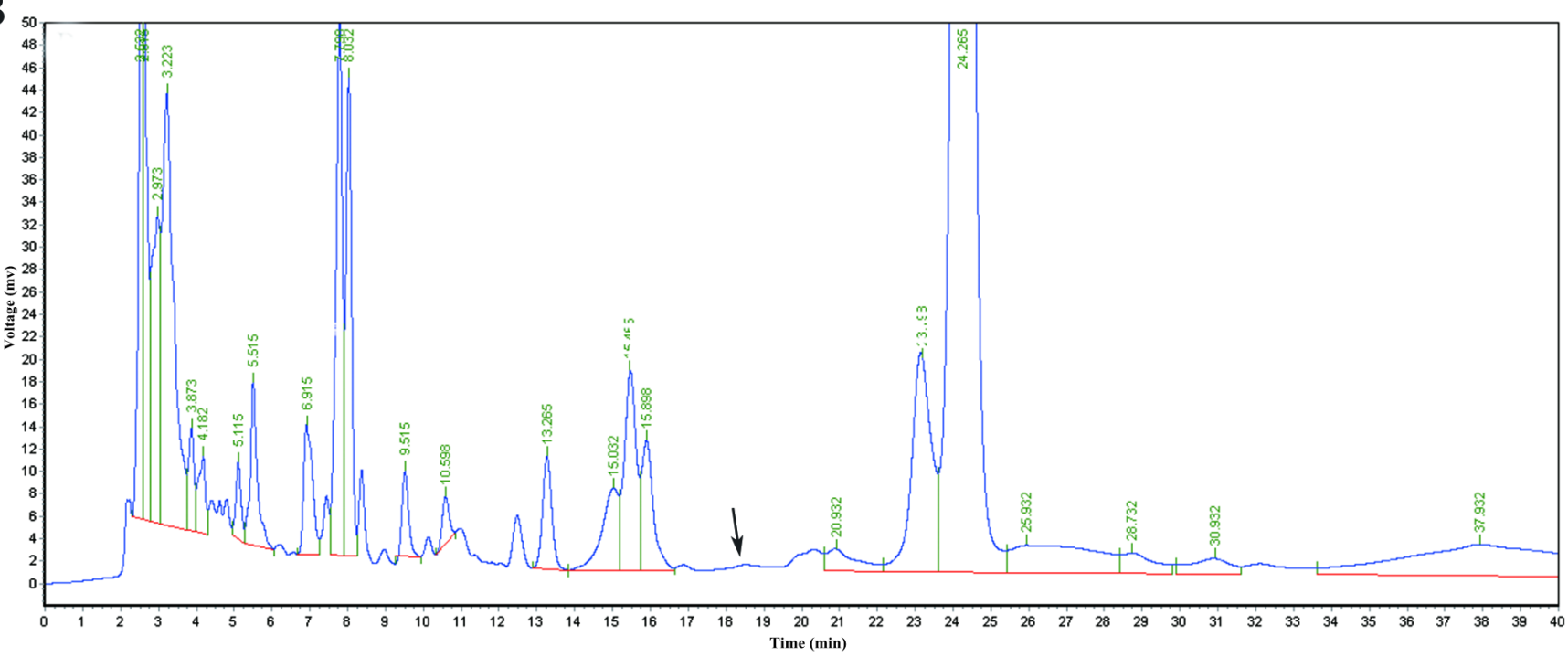

Figure 2. High-performance liquid chromatography profiles of phorbol esters in (A) standardized sample and (B) muscle sample of DJM75. DJM75 was diet in which the detoxified Jatropha curcas kernel meal (DJM) was included in the diets to replace 75\% soybean meal with phorbol esters concentration $13.75 \mathrm{mg} / \mathrm{kg}$ diet. There was no peak between Time 18 and 20 in muscle sample meaning that no phorbol ester was detected.

and G:F of pigs were observed. The observed variation in the growth responses might be ascribed to several factors such as palatability, acceptability of diets, presence of toxic and antinutritional factors, and digestibility of protein and energy in the diets [24].

Jatropha curcas kernel meal contains many kinds of toxins or anti-nutritional factors [9]. Phorbol esters are considered as the most toxic substance in DJM [24], because they have thermal and chemical stability and can not be completely eliminated [9]. In the present study, there were still some residual PEs $(0.11 \mathrm{mg} / \mathrm{g})$ in DJM. The low ADFI might be due to the undesirable characteristics of DJM in terms of taste, smell, texture, and especially the excessive PEs in these diets which had significant negative effects on feed intake $[10,25]$. The rats fed DJM diets showed significantly reduced feed intake and loss of body weight when the PEs concentration made up to 14.4 $\mathrm{mg} / \mathrm{kg}$ diet [25]. The DJM could be fed to pigs up to certain levels without detrimental effects on growth performance because pig's immune system can detoxify low amounts of diet PEs, but it affects growth and development when the rate of PEs deposition exceeded that of metabolism [12,23]. Similarly, Becker and Makkar [26] proved that the threshold level at which PEs appeared to cause adverse effects in carp was 15 $\mathrm{mg} / \mathrm{kg}$ in the diet. The results of growth performance in the present study suggested that the PEs concentration exceeding $5.50 \mathrm{mg} / \mathrm{kg}$ in a diet would decrease the growth performance of growing pigs.

Lower nutrient digestibility and absorption might be the reason for the decreased growth performance. The current study showed that when DJM was used to replace SBM exceed- 
ing 30\% (diet PEs concentration at $5.50 \mathrm{mg} / \mathrm{kg}$ ), it decreased the utilization of energy and nitrogen, enzyme activities and damaged intestinal morphology. Small intestine is the main place for absorption of nutrients. Morphology of the intestine is an important marker reflecting the health of the intestine. The villus height determines the ability of small intestine to absorb nutrients, and the $\mathrm{V} / \mathrm{C}$ is considered as a useful criterion to estimate nutrient absorption capacity of the small intestine [27]. Changes in intestinal morphology such as shorter villi and deeper crypt are associated with the presence of toxins [28]. Chivandi et al [1] observed that all the pigs fed DJM diets in which the PEs were 10.4, 20, 29.6, and $40 \mathrm{mg} / \mathrm{kg}$, respectively showed different degrees of diarrhea and decreased serum $\alpha$-amylase level of all pigs fed DJM, and the research ascribed those as intestinal injury resulted from the residual PEs in the DJM. Consistently, we found that the intestinal development was restricted and the structure of jejunal villus changed such as disorder and breaking when the replacement of SBM by DJM up to 75\% in the present study. Wang [29] also discovered reduced villus height of duodenum and jejunum in chickens fed DJM diets. Similar experimental evidence was also observed in common carp fingerlings and rats. Feeding trials on common carp and rats with excessive PEs concentration in the diets have been reported to cause marked damage in intestinal structure and reduction in digestive absorption of protein and energy utilization [29]. Poor digestion and absorption would seriously affect the animal's growth and health. The diarrhea in this study might be caused by the interplay of maldigestion and malabsorption of nutrients. Diarrhea was also been found in feeding trials on common carp and rats with Jatropha meal containing PEs $[11,30]$. The reason the lipase in DJM45 does not decrease may be that a different enzyme has a different tolerance for toxins. Kumar et al [16] also found that the lipase activity would not be affected when the DJM replaced $50 \%$ of fish meal protein though amylase and protease activities were decreased. Therefore, the PEs concentration exceeding $5.50 \mathrm{mg} / \mathrm{kg}$ in a diet could damage the structure of the small intestine and affect adversely the function of absorption, and then decreased growth performance of growing pigs.

It has been certified that DJM could replace SBM and did not impact the health and production of growing pigs [17]. The previous study showed that no PEs were detected in the livers which are the main metabolic organ of PEs [12]. Accordingly, there was no PEs detected in the muscles by HPLC. The detection limit of PEs is $3 \mu \mathrm{g} / \mathrm{g}$ samples which suggested that the PEs concentration was less than $3 \mu \mathrm{g} / \mathrm{g}$ in the muscles. Makkar and Becker $[14,15]$ reported that the PEs concentration in the edible Jatropha seed was $0.11 \mathrm{mg} / \mathrm{g}$. It indicated that feeding DJM to the pigs would not influence the edibility of meat, which was similar to the result of feeding trial on common carp that no muscle morphology was found in all groups [23].
Above all, DJM in which PEs concentration was $0.11 \mathrm{mg} / \mathrm{g}$ could be used to replace SBM for CP supply by maximum 30\% (diet PEs concentration at $5.5 \mathrm{mg} / \mathrm{kg}$ ) in growing pig diet, and does not impact the production of growing pigs and the health of human beings. Besides, an economical and efficient detoxification method should be developed for the application of DJM in the pig production industry to reduce feed cost.

\section{CONCLUSION}

The results obtained in the present study indicated that DJM could be used to replace SBM for CP supply up to a maximum $30 \%$ (diet PEs concentration at $5.5 \mathrm{mg} / \mathrm{kg}$ ) in growing pig diet with no effects on growth performance, nutrient utilization, and meat edibility of growing pigs.

\section{CONFLICT OF INTEREST}

We certify that there is no conflict of interest with any financial organization regarding the material discussed in the manuscript.

\section{ACKNOWLEDGMENTS}

We are grateful to the Xian Oil-Fats Research Design Institute of State Grain Reserve Bureau and CNOOC for providing DJM. This study was supported by the National Public Welfare Research Project (201203015) and the Program for Changjiang Scholars and Innovative Research Team in University of Ministry of Education of China (IRT13083). Please check again!

\section{REFERENCES}

1. Chivandi E, Erlwanger KH, Makuza SM, Read JS, Mtimuni JP. Effects of dietary Jatropha curcas meal on percent packed cell volume, serum glucose, cholesterol and triglyceride concentration and alpha-amylase activity of weaned fattening pigs. Res J Anim Vet Sci 2006;1:18-24.

2. Openshaw KA. A review of Jatropha curcas: an oil plant unfulfilled promise. Biomass Bioenergy 2000;19:1-15.

3. Andrew JK. Potential of Jatropha curcas as a source of renewable oil and animal feed. J Exp Bot 2009;60:2897-905.

4. Adam SEI. Toxic effects of Jatropha curcas in mice. Toxicology 1974;2:67-76.

5. Liberalino AAA, Bambirra EA, Moraes-Santos T, Viera CE. Jatropha curcas L. seeds: chemical analysis and toxicity. Arquivos de Biologia e Tecnologia 1988;31:539-50.

6. El-Badwi SM, Adam SE. Toxic effects of low levels of dietary Jatropha curcas seed on brown Hisex chicks. Vet Hum Toxicol 1992;34:112-5.

7. Makkar HPS, Becker K, Sporer F, Wink M. Studies on nutritive potential and toxic constituents of different provenanaces of 
Jatropha curcas. J Agric Food Chem 1997;45:3152-7.

8. Makkar HPS, Aderibigbe O, Becker K. Comparative evaluation of non-toxic and toxic varieties of Jatropha curcas for chemical composition, digestibility, protein degradability and toxic factors. Food Chem 1998;62:207-15.

9. Makkar HPS, Becker K. Jatropha curcas toxicity: identification of toxic principle(s). 5th International Symposium on Poisonous Plants; 2007a May 19 -23; San Angelo, TX, USA.

10. Makkar HPS, Becker K. Potential of J. curcas seed meal as a protein supplement to livestock feed, constraints to its utilization and possible strategies to overcome constraints. In: Gubitz GM, Mittelbach M, Teabi M, editors. Biofuels and industrial products from Jatropha curcas. Managua, Nicaragua: DBV fur die Technische Universitat Graz; 1997. pp. 190-205.

11. Kumar V, Makkar HPS, Becker K. Detoxified Jatropha curcas kernel meal as a dietary protein source: growth performance, nutrient utilization and digestive enzymes in common carp (Cyprinus carpio L.) fingerlings. Aquac Nutr 2011;17:313-26.

12. Li Y, Chen L, Lin Y, et al. Effects of replacing soybean meal with detoxified Jatropha curcas kernel meal in the diet on growth performance and histopathological parameters of growing pigs. Anim Feed Sci Technol 2015;204:18-27.

13. Latimer GW. AOAC International. Official methods of analysis of AOAC International. 19th ed. Gaithersburg, MD, USA: AOAC International; 2012.

14. Bassler R, Buchholz H. Amino acid analysis. Methodenbuch: Die Chemische Untersuchung von Futtermitteln 1993;3:1-5.

15. Pinter-Szakacs M, Molnar-Perl I. Determination of tryptophan in unhydrolyzed food and feedstuffs by the acid ninhydrin method. J Agric Food Chem 1990;38:720-6.

16. Committee on Nutrient Requirements of Swine, National Research Council. Nutrient requirements of swine. 10th ed. Washington, DC, USA: National Academy Press; 1998.

17. Marquardt RR, Jin LZ, Kim JW, et al. Passive protective effect of egg-yolk antibodies against enterotoxigenic Escherichia coli K88+ infectionin neonatal and early-weaned piglets. FEMS Immunol Med Microbiol 1999;23:283-8.

18. Jin L, Reynolds LP, Redmer DA, Caton JS, Crenshaw JD. Effects of dietary fiber on intestinal growth, cell proliferation, and morphology in growing pigs. J Anim Sci 1994;72:2270-8.
19. Smith C, VanMegen W, Twaalfhoven L, Hitchcook C. The determinations of trypsin inhibitor levels in foodstuffs. J Agric Food Chem 1980;31:341-50.

20. Liu K, Markakis P. Trypsin inhibition assay as related to limited hydrolysis of inhibitors. Anal Biochem 1980;178:159-65.

21. Makkar HPS, Francis G, Becker K. Bioactivity of phytochemicals in some lesser-known plants and their effects and potential applications in livestock and aquaculture production systems. Animal 2007;1:1371-91.

22. Kong C, Adeola O. Evaluation of amino acid and energy utilization in feedstuff for swine and poultry diets. Asian-Australas J Anim Sci 2014;27:917-25.

23. Makkar HPS. State-of-the-art on detoxification of Jatropha curcas products aimed for use as animal and fish feed: a review. Anim Feed Sci Technol 2016;222:87-99.

24. Kumar V, Makkar HPS, Amselgruber W, Becker K. Physiological, haematological and histopathological responses in common carp (Cyprinus carpio L.) fingerlings fed with differently detoxified Jatropha curcas kernel meal. Food Chem Toxicol 2010;48:2063-72.

25. Aregheore EM, Becker K, Makkar HPS. Detoxification of a toxic variety of Jatropha curcas using heat and chemical treatments, and preliminary nutritional evaluation with rats. South Pac J Natur Appl Sci 2003;21:51-6.

26. Becker K, Makkar HPS. Effects of phorbol esters in carp (Cyprinus carpio L.). Vet Hum Toxicol 1998;40:82-6.

27. Heo JM, Opapeju FO, Pluske JR, et al. Gastrointestinal health and function in weaned pigs: a review of feeding strategies to control post-weaning diarrhoea without using in-feed antimicrobial compounds. J Anim Physiol Anim Nutr 2013;97: 207-37.

28. Yason CV, Summers BA, Schat KA. Pathogenesis of rotavirus infection in various age groups of chickens and turkeys: pathology. Am J Vet Res 1987;48:927-38.

29. Wang DG. Research of effects and mechanism of Jatropha curcas kernel meal on performance and health in broilers [Ph.D. Thesis]. Sichuan, China: Sichuan Agricultural University; 2012.

30. Rakshit KD, Darukeshwara J, Rathina Raj K, et al. Toxicity studies of detoxified Jatropha meal (Jatropha curcas) in rats. Food Chem Toxicol 2008;46:3621-5. 